УДК 796.22;796.07

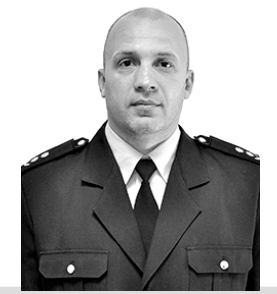

О. А. Моргунов

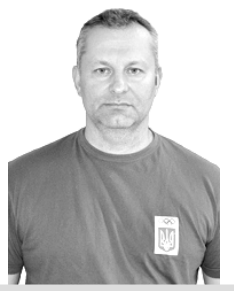

О. А. Ярещенко

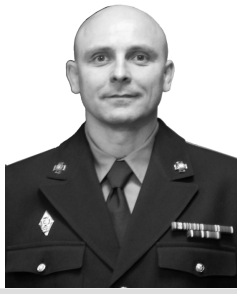

О. В. Хацаюк

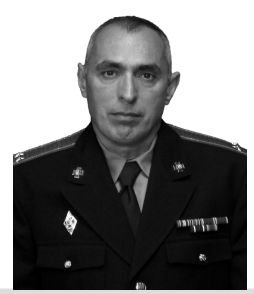

Ю. К. Белошенко

\title{
РОЗРОБКА ТЕХНІКИ РУКОПАШНОГО БОЮ ПРАВООХОРОНЦІВ МВС УКРАЇНИ В СИСТЕМІ СПЕЦІАЛЬНОЇ ФІЗИЧНОЇ ПІДГОТОВКИ
}

Подано результати проведеної апробаиії експериментальної техніки обеззброєння супротивника, озброєного холодною зброєю, під час навчально-тренувальних занять зі спеціальної фізичної підготовки. Викладено результати експериментальних досліджень, спрямованих на підвищення

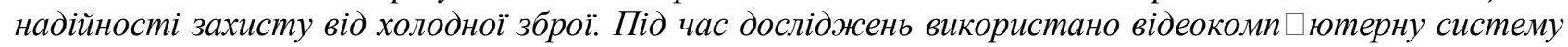
експрес-аналізу техніки єдиноборств (ВКС “Каtsuтото”). Відповідно до отриманих результатів розроблено експериментальні моделі техніки обеззброєння, які під час апробації значною мірою підвищили технічний арсенал курсантів - майбутніх правоохоронців МВС Украӥни.

Ключові слова: спеціальна фізична підготовка, військовослужбовиі, полічейські, спеціальнопідготовчі вправи, технічна підготовка, сучасні технічні засоби навчання, захист від загрози холодною зброєю, обеззброєння, правопорушник, супротивник.

Постановка проблеми. На цей час питання вирішення проблеми реалізації комплексу заходів, спрямованих на створення умов ефективної протидії злочинності в Україні, продовжують залишатися гострими й актуальними. Про це свідчать численні випадки нападів на працівників правоохоронних органів, нерідко із застосуванням холодної та вогнепальної зброї, що, своєю чергою, призводить до важких травм, поранень та навіть загибелі. 3 огляду на викладене вище від навчальних закладів освіти MBC України вимагається приділити особливу увагу напрямку вдосконалення професійної підготовленості правоохоронців, складником якої є спеціальна фізична підготовленість.

Слід зазначити, що програми професійного становлення майбутніх офіцерівправоохоронців МВС України грунтуються на виконанні вимог законів України "Про Національну поліцію України" [1] та "Про Національну гвардію України" [2]. У свою чергу, до науково-педагогічних працівників кафедр спеціальної фізичної підготовки закладів вищої освіти МВС України висуваються високі вимоги, якими передбачено постійне вдосконалювання техніки виконання прийомів захисту та обеззброєння правопорушників. Крім цього $\epsilon$ також необхідність поліпшення методики навчання правоохоронців спеціальним прийомам та діям рукопашного бою, що, своєю чергою, $\epsilon$ актуальним напрямком наукових досліджень.

Аналіз останніх досліджень і публікацій. Проведений аналіз науково-методичної літератури стосовно напрямку заходів фізичного впливу, анкетування провідних фахівців галузі єдиноборств, результати попередніх науково-дослідних робіт [3], спрямованих на вдосконалення техніки рукопашного бою, особистий досвід виступу на змаганнях різних рівнів зі службовоприкладних єдиноборств, бойовий досвід, а також тривалий педагогічний досвід викладання дисципліни "Спеціальна фізична підготовка" підтверджують необхідність постійного вдосконалювання техніки захисту та обеззброєння супротивника, озброєного ножем.

У дослідженні нашу увагу привернули праці таких авторів, як О. А. Моргунов (2014 р.) [4, 5], Ю. В. Вареньга (2015 р.) [6], О. В. Хацаюк, О. А. Гаркавий та ін. (2018р.) [7]. У згаданих працях розкрито загальні питання організації системи спеціальної фізичної підготовки у закладах вищої освіти МВС України.

Під час аналізу науково-методичної літератури інтерес становили праці 
В. О. Артем'єва (2011 р.) [8], О. А. Моргунова, О. А. Ярещенка (2017р.) [9], у яких розкрито основні технічні складові навчання техніці обеззброєння супротивника, озброєного холодною та вогнепальною зброєю, на початковому етапі навчання.

Своєю чергою, у працях О. С. Скирти (2014 p.) [10], О. А. Моргунова, О. А. Ярещенка (2016 р.) [11], О. В. Хацаюка (2018 р.) [12] розкрито питання навчання та вдосконалення техніки службово-прикладних єдиноборств, які забезпечують успішне проходження розділу "Рукопашний бій" навчальної дисципліни "Спеціальна фізична підготовка".

Цікавими і прийнятними для застосування на практиці виявилися праці К. В. Ананченка (2016 p.) [13], О. А. Соколова (2016 р.) [14], О. А. Ярещенка, О. А. Моргунова (2017 р.) [15], у яких підкреслюється важливість використання сучасних технологій (технічних засобів навчання) у навчально-тренувальному процесі правоохоронців з рукопашного бою.

Незважаючи на значну кількість праць зазначеного напрямку досліджень, питанням удосконалення технічного арсеналу захисту та обеззброєння супротивника шляхом використання техніки “м'якого" блокування проти ударів ножем нами не виявлено.

Одним із ефективних шляхів вирішення наведеної проблеми $€$ використання на практиці для захисту від ударів ножем так званого “м'якого” блокування озброєної руки супротивника. Застосування цього виду захисту пов'язано 3 активним відходом від лінії атаки, переведенням озброєної руки супротивника вбік з подальшим ії контролем. У результаті цього розширюється зона безпеки правоохоронця i водночас зменшується можливість завдання ударів вільною від захоплення рукою з боку супротивника. Таким чином, очевидною стає перевага "м'якого" блокування ударів ножем супротивником у порівнянні 3 використанням традиційного “жорсткого” блокування.

Мета статті - моделювання й обгрунтування більш надійного захисту та обеззброєння супротивника шляхом використання техніки “м'якого" блокування проти ударів ножем.

Виклад основного матеріалу. На базі Національної академії Національної гвардії України та Харківського національного університету внутрішніх справ було проведено педагогічний експеримент, яким передбачено здійснення

порівняльного

аналізу

ефективності захисту шляхом застосування "м’якого" та “жорсткого” блокування ударів ножем.

У педагогічному експерименті взяли участь курсанти молодших курсів у кількості 40 осіб. Ïх розподілили на 2 групи: експериментальну (Ег) та контрольну (Кг) по 20 осіб (вік досліджуваних 18-23 роки). Слід зауважити, що на початку педагогічного експерименту досліджувані курсанти за рівнем технічної підготовленості 3 рукопашного бою не розрізнялися.

Тривалість експерименту склала три місяці, упродовж яких було проведено 36 практичних занять по 90 хв кожне. Навчально-тренувальні заняття 3 рукопашного бою проводилися в години спортивно-масової роботи відповідно до вимог програми за темою "Захист від загрози холодною зброєю”. Варто зазначити, що до початку педагогічного експерименту курсанти Ег та Кг володіли мінімальним арсеналом техніки “жорсткого" блокування ударів ножем 3 подальшим обеззброєнням супротивника шляхом використання больових прийомів: "важіль руки до середини", "важіль руки назовні”, “вузол руки”.

Таким чином, учасникам Ег необхідно було спершу опанувати техніку "м'якого" блокування та поєднати ¥іі 3 технікою виконання вказаних вище больових прийомів і лише після цього приступити до вдосконалення техніки обеззброєння супротивника в цілому.

У свою чергу, представники КГ з перших занять приступили до повторного вдосконалювання раніше вивченої техніки традиційного “жорсткого” блокування протидій супротивника 3 подальшим його обеззброєнням шляхом застосування зазначених вище прийомів.

Оцінювання якості виконання прийомів захисту та обеззброєння проводилося за п'ятибальною шкалою в Ег та Кг експертною групою (фахівці службово-прикладних єдиноборств) у складі: кандидата юридичних наук, доцента, ЗТУ 3 кікбоксингу О. А. Моргунова (ХНУВС), ЗТУ з кікбоксингу О. В. Хацаюка (НАНГУ), кандидата наук 3 фізичного виховання i спорту доцента О. А. Ярешенка (ХНУВС), КМСУ Ю. К. Белошенка (НАНГУ). Своєю чергою, аналіз вихідного рівня технічної підготовленості тих, хто навчається, до виконання захисних дій 3 наступним 
обеззброюванням супротивника подано у табл. 1 .

Слід зазначити, що складність оволодіння технікою "м'якого" блокування ударів ножем висуває підвищені вимоги до координаційних здібностей тих курсантів, хто навчаються, що, своєю чергою, потребує підвищеної уваги до методики навчання. Крім цього, 3 метою активізації тактильного сприйняття i координації рухів нами були розроблені та практично апробовані під часпрактичних тренувань комплекси спеціально-підготовчих вправ (наведено у табл. 2), які впливають на вид хвату ножа (утримання рукоятки), а також вид та напрям удару (тобто зону ураження).

Упродовж педагогічного експерименту використовувалася відекомп'ютерна система експрес-аналізу техніки єдиноборств ВКС "Katsumoto" [16], яка дозволила визначити параметри та траєкторію переміщення загального центру маси (ЗЦМ) правоохоронців у просторі під час виконання ними прийомів захисту та обеззброєння.

Порівняння траєкторій руху ЗЦМ тих, хто був перевірений 3 різним рівнем підготовленості, дає змогу швидко находити й усувати технічні помилки, які виникають або можуть виникати у процесі практичного відпрацювання прийомів обеззброєння рукопашного бою.

На рисунках 1, 2, 3 наведено дані траєкторії переміщення ЗЦМ спортсмена вищої кваліфікації зі службово-прикладних єдиноборств (ЗМСУ 3 кікбоксингу А. Г. Василенка), який застосовує техніку “м'якого" блокування проти ударів ножем: прямо, навідліг та збоку. Ця техніка $\epsilon$ еталонною і дозволяє достовірно проводити порівняльний аналіз технічних дій рукопашного бою тих, кого тестують 3 рукопашного бою.

У свою чергу, навчальна програма занять експериментальної групи реалізовувалася впродовж чотирьох етапів (дані наведено у табл. 3).

Слід зауважити, що на заняттях № 1-13 (табл. 3) вирішувалося завдання навчання прийомам “м'якого” блокування проти ударів озброєної руки. При цьому заняття № 1-7 (табл. 3) були спрямовані на ознайомлення 3 технікою "м'якого" блокування ударів; заняття № 8-13 (табл. 3) на його вдосконалення. Заняття № 14-24 (табл. 3) були спрямовані на поєднання техніки “м'якого” блокування озброєної ножем руки супротивника і його обеззброєння шляхом застосування техніки рукопашного бою, у якій використовуються важелі, що, своєю чергою, регламентовано керівними документами 3 організації фізичної та спеціальної фізичної підготовки в системі MBC України $\quad[17, \quad 18]$.

Т а б ли ц я 1

Очінка техніки захисту та обеззброєння тих, хто навчається, на початку експерименту (бали, $n=40$ )

\begin{tabular}{|c|c|c|c|c|}
\hline $\begin{array}{c}\text { Контрольна група }(\mathrm{n}=20) \\
\mathrm{x} \square \mathrm{K}^{\prime} \pm \mathrm{m}\end{array}$ & $\begin{array}{c}\text { Експериментальна група }(\mathrm{n}=20) \\
\mathrm{x} \square \mathrm{E} \pm \mathrm{m}\end{array}$ & $\Delta$ & $\mathrm{T}$ & $\mathrm{p}$ \\
\hline $3,31 \pm 0,15$ & $3,14 \pm 0,18$ & 0,17 & 0,23 & $>0,05$ \\
\hline
\end{tabular}

Т а б ли и я 2

Комплекси спечіально-підготовчих вправ, які впливають на вид хвату ножа, а також вид та напрям удару

\begin{tabular}{|c|c|c|c|}
\hline Вид удару & Хват ножа & Зона ураження & $\begin{array}{c}\text { Комплекс спеціально- } \\
\text { підготовчих вправ }\end{array}$ \\
\hline $\begin{array}{c}\text { Захист від удару ножем } \\
\text { зверху та збоку }\end{array}$ & Зовнішній & $\begin{array}{c}\text { Обличчя } \\
\text { Шия }\end{array}$ & “Обкатка" з лівої руки \\
\hline $\begin{array}{c}\text { Захист від удару ножем } \\
\text { навідліг }\end{array}$ & Зовнішній & $\begin{array}{c}\text { Обличчя } \\
\text { Шия }\end{array}$ & $\begin{array}{c}\text { “Обкатка" з правої } \\
\text { руки }\end{array}$ \\
\hline $\begin{array}{c}\text { Захист від удару ножем } \\
\text { прямо }\end{array}$ & Зовнішній & $\begin{array}{c}\text { Обличчя } \\
\text { Шия } \\
\text { Низ живота }\end{array}$ & $\begin{array}{c}\text { “Вісімка" } \\
\text { Збиття руки } \\
\text { Переведення }\end{array}$ \\
\hline
\end{tabular}




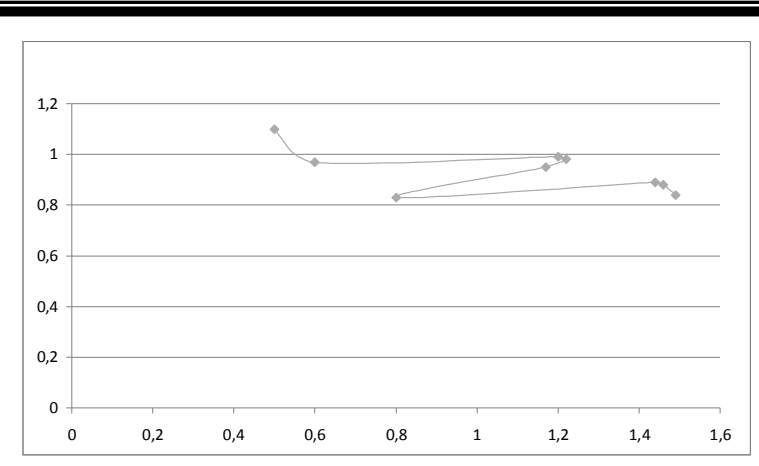

Рис. 1. Траєкторія руху ЗЦМ спортсмена вищої кваліфікації під час виконання захисту від удару ножем навідліг (вимірюється у метрах)

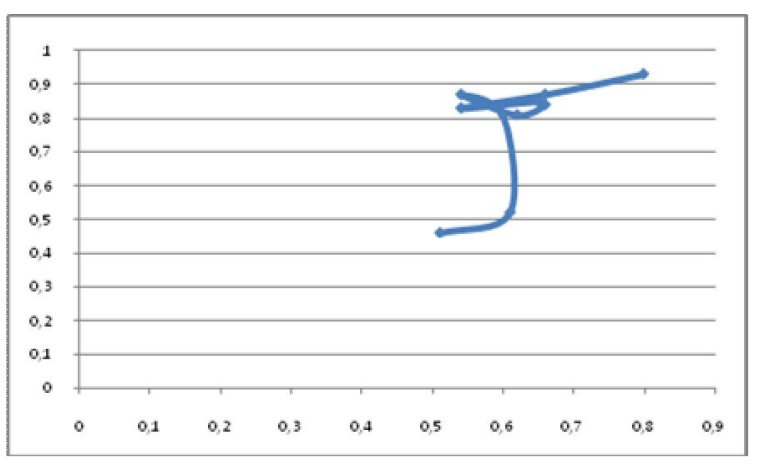

Рис. 2. Траєкторія руху ЗЦМ спортсмена вищої кваліфікації під час виконання захисту від удару ножем прямо (вимірюється у метрах)

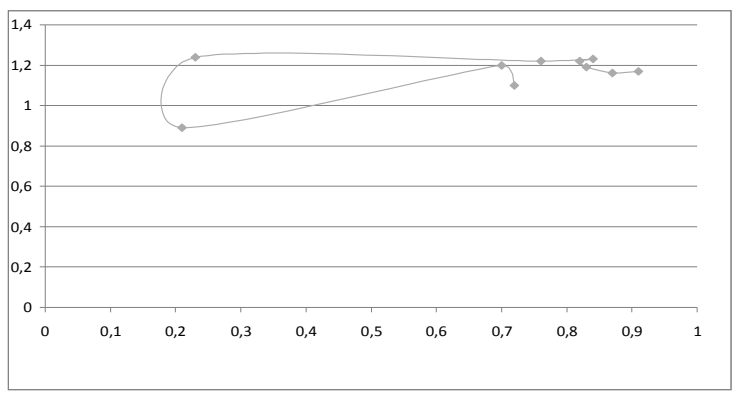

Рис. 3. Траєкторія руху ЗЦМ спортсмена вищої кваліфікації під час виконання захисту від ударуножем зверху, збоку (вимірюється у метрах)
Відповідним чином на заняттях № 25-28 (табл. 3) удосконалювалися техніки больового контролю супротивника, одягання наручників, поверхневого огляду та конвоювання. Заняття № 29-36 (табл. 3) були спрямовані на узгодження всіх елементів комплексу технічних дій: “м'якого” блокування, обеззброєння, больового контролю, одягання наручників, поверхневого огляду та конвоювання.

Під час педагогічного експерименту встановлено, що представники Ег успішно оволоділи технікою “м'якого" блокування ударів 3 подальшим обеззброєнням супротивника. Про це свідчать експертні оцінки, які подано на рис. 4 і 5.

Наприкінці педагогічного експерименту (заняття № 36) експертна група оцінила дії всіх курсантів-правоохоронців, хто навчався, під час виконання захисту від ударів ножем 3 подальшим обеззброєнням супротивника. Одержані результати тестування свідчать про те, що представники Ег мали кращі показники на відміну від представників Кг (дані наведено у табл. 4).

Таким чином, перевага Ег над Кг була досягнута виключно за рахунок застосування більш надійного й ефективного "м'якого" блокування ударів ножем, що завдає супротивник.

Решта технічного арсеналу рукопашного бою представниками Ег та Кг виконувалася відповідно до вимог керівних документів (наказів, настанов) 3 організації фізичної підготовки (спеціальної фізичної підготовки) у системі МВС України $[17,18]$.

У свою чергу, головне завдання педагогічного експерименту - довести перевагу техніки "м'якого" блокування ударів над технікою “жорсткого” - виконано і підтверджено даними математичної статистики.

Т а б ли ц я 3

Поетапне виконання завдань навчання

\begin{tabular}{|c|c|c|c|}
\hline Етап & Завдання етапу & Заняття & Контрольні заняття \\
\hline 1 & $\begin{array}{l}\text { Ознайомлення і вивчення прийомів “м’якого” } \\
\text { блокування }\end{array}$ & № 1-13 & $\begin{array}{l}\text { № 4, № } 7 \text {, № } 10, \\
\text { № } 13\end{array}$ \\
\hline 2 & $\begin{array}{l}\text { 1. Удосконалення техніки “м’якого" } \\
\text { блокування від удару ножем. } \\
\text { 2. Удосконалення техніки больового контролю } \\
\text { озброєної руки правопорушника }\end{array}$ & № 14-20 & № 16, № 20 \\
\hline 3 & $\begin{array}{l}\text { Відпрацювання технік обеззброєння, } \\
\text { одягання наручників, поверхневої перевірки } \\
\text { та конвоювання }\end{array}$ & № 21-28 & № 24, № 28 \\
\hline 4 & Виконання прийомів і захисних дій у цілому & № 29-36 & № 32, № 36 \\
\hline
\end{tabular}




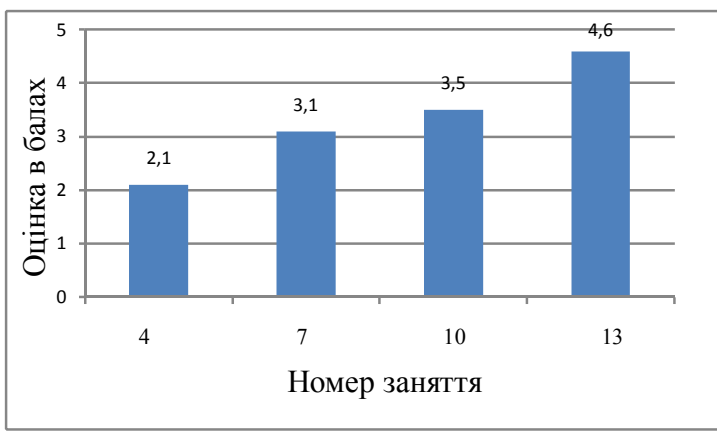

Рис. 4. Динаміка успішності оволодіння прийомами “м'якого”блокування озброєної руки супротивника представниками Ег (бали, заняття № 1-13)

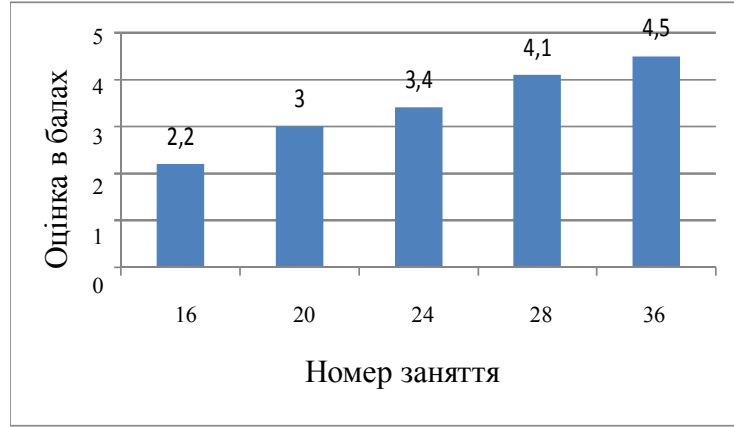

Рис. 5. Динаміка успішності виконання комплексу прийомів і дій у цілому представниками Ег (бали, заняття № 14-36)

Т а б л и ц я 4

Результати експертної оцінки демонстрації техніки захисту від холодної зброї та обеззброєння представниками Кг та Ег - курсантами ХНУВС та НАНГУ (бальна шкала, $n=40)$

\begin{tabular}{|c|c|c|c|c|c|}
\hline Показник (ТТК) & $\begin{array}{c}\text { Контрольна } \\
\text { група } \\
(\mathrm{n}=20)\end{array}$ & $\begin{array}{c}\text { Експериментальна } \\
\text { група } \\
(\mathrm{n}=20)\end{array}$ & $\mathrm{t}$ & $\mathrm{P}$ & 3,52 \\
\hline $\begin{array}{c}\text { Захист від удару ножем } \\
\text { збоку та обеззброєння }\end{array}$ & $2,76 \pm 0,11$ & $3,64 \pm 0,23$ & 0,88 & 3,06 & $<0,01$ \\
\hline $\begin{array}{c}\text { Захист від удару ножем } \\
\text { прямо та обеззброєння }\end{array}$ & $2,88 \pm 0,13$ & $3,43 \pm 0,12$ & 0,55 & 2,42 & $<0,05$ \\
\hline $\begin{array}{c}\text { Захист від удару ножем } \\
\text { навідліг та обеззброєння }\end{array}$ & $2,97 \pm 0,14$ & $3,48 \pm 0,17$ & 0,51 & \\
\hline
\end{tabular}

\section{Висновки}

У результаті дослідження проведено моделювання та апробацію ефективної техніки захисту й обеззброєння супротивника шляхом використання техніки “м'якого” блокування проти ударів ножем.

Виконання завдань за призначенням правоохоронцями МВС України вимагає від них постійного вдосконалювання індивідуального рівня спеціальної фізичної підготовленості, важливою частиною якої $€$ вміння застосувати прийоми захисту від холодної зброї.

Крім цього захист від ударів ножем супротивника базується на використанні правоохоронцем так званого “жорсткого” блокування озброєної руки правопорушника. Надалі обеззброєння супротивника здійснюється за допомогою застосування спеціальних больових прийомів (“важіль руки до середини”, “важіль руки назовні” і “вузол руки”), проте “жорстке” блокування ударів має істотний недолік - недостатній контроль руки, яка вільна від захоплення. Складним є також і збільшення зони безпеки від удару чи контрудару супротивником, у свою чергу, “м'яке" блокування ударів супротивника вирішує вказану проблему, що підтверджено результатами дослідження.

Також успішність використання “м'якого” блокування ударів ножем i обеззброєння правопорушника багато в чому залежить від рівня розвитку координаційних здібностей правоохоронця. Тому розроблені у процесі дослідження спеціально-підготовчі вправи, які враховують спосіб завдання удару та спосіб хвату рукоятки ножа, водночас поліпшують навчання i вдосконалення прийомів захисту від ударів та обеззброєння правопорушника, а також значно покращують координаційні здібності тих курсантів НАНГУ та ХНУВС, що навчаються.

У свою чергу, відеокомп'ютерна система BKC “Katsumoto", яка була використана для побудови траєкторії руху загального центру маси у бойовому просторі під час виконання захисту та обеззброєння, дозволила у 
подальшому своєчасно й ефективно коригувати технічні помилки досліджуваних курсантів.

Розроблені та практично апробовані під час педагогічного експерименту моделі техніки обеззброєння супротивника, озброєного ножем, впроваджені у навчальнотренувальний процес зі спеціальної фізичної підготовки НАНГУ та ХНУВС.

Перспективи подальших розробок у даному напрямку передбачають удосконалення техніки та тактики під час обеззброєння правопорушників, озброєних вогнепальною зброєю, на близькій дистанції. Крім цього, планується дослідити такі психологічні якості правоохоронців, що впливають на виконання завдань за призначенням в умовах рукопашної сутички із правопорушником.

\section{Список використаних джерел}

1. Про Національну поліцію [Електронний ресурс] : Закон України (Відомості Верховної Ради України, 2015, № 40-41, ст. 379). - Режим доступу : http://zakon2.rada.gov.ua/laws/card/580 -19 (дата звернення : 27.08.2017). - Назва 3 екрана.

2. Про Національну гвардію України [Електронний ресурс] : Закон України (Відомості Верховної Ради України, 2014, № 17, ст. 594). - Режим доступу : http://zakon3.rada.gov.ua/laws/show/876-18 (дата звернення : 20.06.2017). - Назва з екрана.

3. Хацаюк, O. В. Удосконалення спеціальної фізичної підготовленості військовослужбовців внутрішніх військ МВС України у системі бойової підготовки [Текст] / O. В. Хацаюк // Збірник наукових праць Академії внутрішніх військ МВС України. Харків : Акад. ВВ МВС України, 2013. Вип. 1. - С. 66-72.

4. Загальна фізична підготовка працівників Національної поліції України [Текст] : метод. рек. / [уклад. : О. А. Моргунов, О. А. Соколов, М. Г. Калюжний, Є. А. Лозовий] ; МВС України, Харків. нац. ун-т внутр. справ ; за заг. ред. В. В. Сокуренка. - Харків : ХНУВС, 2017. $-124 \mathrm{c}$.

5. Моргунов, О. А. Удосконалення фізичної підготовки правоохоронців МВС України на початковому етапі навчання [Текст] / О. А. Моргунов // Честь і закон. - 2014. - № 2. - C. 46-49.

6. Вареньга, Ю. В. Удосконалення фізичної підготовки працівників МВС України на етапі професійного становлення [Текст] : дис. ... канд. наук $з$ фіз. вих. і спорту : 24.00.02 / Ю. В. Вареньга. - Львів, 2015. - 262 с.

7. Організація фізичної підготовки у навчальних закладах НГУ [Текст] : навч. посіб. / О. В. Хацаюк, О. А. Гаркавий, А. В. Стаднік, К. В. Ананченко. - Харків : НАНГУ, 2018. $260 \mathrm{c}$.

8. Артем'єв, В. О. Спеціальна фізична підготовка працівників ОВС України [Текст] : підручник / В. О. Артем'єв, О. А. Ярещенко, В. В. Сергієнко. - Харків : Харків юридичний, 2011. - $256 \mathrm{c}$.

9. Застосування заходів фізичного впливу для затримання правопорушника, озброєного холодною зброєю [Текст] : метод. рек. / [уклад. О. А. Моргунов, О. А. Ярещенко] ; МВС України, Харків. нац. ун-т внутр. справ. Харків : ХНУВС, 2017. - 28 с.

10. Дослідження завадостійкості кікбоксерів у розділі орієнтал на етапі спеціалізованої базової підготовки [Текст] / О. Скирта, В. Горбенко, О. Хацаюк, О. Пікінер // Спортивний вісник Придністров'я. - 2014. № 3. - С. 110-116.

11. Моргунов, О. А. Методика подготовки будущих сотрудников Национальной полиции Украины к применению мер полицейского принуждения [Текст] / О. А. Моргунов, О. А. Ярещенко // Підготовка поліцейських в умовах реформування системи МВС України : 3б. матеріалів / МВС України, Харк. нац. ун-т внутр. справ. - Харків : ХНУВС, 2017. C. $106-111$.

12. Ананченко, К. В. Особливості тренувального процесу та техніко-тактичної підготовленості дзюдоїстів-ветеранів [Текст] / К. В. Ананченко, О. В. Хацаюк // Єдиноборства. - Харків : ХДАФК, 2018. № 14. - C. 4-18.

13. Ананченко, К. В. Побудова річного циклу в групах спортивного вдосконалення курсантів-єдиноборців [Електронний ресурс] / К. В. Ананченко, С. Л. Пакулін, Ю. К. Белошенко // Traektoriâ Nauki. - 2016. № 8 (13). - Режим доступу : http://pathofscience.org/index.php/ps/article/view/211 (дата звернення : 27.08.2016). - Назва з екрана.

14. Хацаюк, O. В. Перспективи застосування сучасних технічних засобів навчання під час навчально-тренувальних занять зі спеціальної фізичної підготовки [Текст] / О. В. Хацаюк, О. А. Соколов // Підготовка поліцейських в умовах реформування системи МВС України : зб. 
матеріалів / МВС України, Харк. нац. ун-т внутр. справ. - Харків : ХНУВС, 2016. C. $167-170$.

15. Хацаюк, О. В. Напрямки розвитку військово-прикладних навичок застосування засобів індивідуального захисту та активної оборони курсантами-правоохоронцями [Текст] / О. В. Хацаюк, О. А. Моргунов, О. А. Ярещенко // Честь і закон. - 2017. № 63. - С. 49-56.

16. Удосконалення техніки рукопашного бою правоохоронців МВС України із використанням сучасних технічних засобів навчання [Текст] : звіт про НДР : Модель-РБ / кер. Д. О. Каратаєва, вик. О. В. Хацаюк. Харків : Акад. ВВ МВСУ, 2008. - 148 с. - № 0108U007536.
17. Про затвердження Положення про організацію службової підготовки працівників Національної поліції України [Електронний ресурс] : наказ Міністерства внутрішніх справ України № 50 від 26.01.2016 р. - Режим доступу : http://zakon3.rada.gov.ua/laws/show/z0 260-16//17 (дата звернення : 21.08.2017). Назва 3 екрана.

18. Інструкція 3 організації фізичної підготовки в Національній гвардії України [Текст] / С. В. Лещеня, I. П. Орленко, А. О. Мелешко, С. С. Забродський ; за заг. ред. О. Н. Мальцева. - Київ : ГУ НГУ, 2014. $140 \mathrm{c}$.

Стаття надійшла до редакиії 03.12.2018 p.

\title{
УДК 796.22;796.07
}

\section{А. А. Моргунов, О. А. Ярещенко, А. В. Хацаюк, Ю. К. Белошенко}

\section{РАЗРАБОТКА ТЕХНИКИ РУКОПАШНОГО БОЯ ПРАВООХРАНИТЕЛЯМИ МВД УКРАИНЫ В СИСТЕМЕ СПЕЦИАЛЬНОЙ ФИЗИЧЕСКОЙ ПОДГОТОВКИ}

Представлены результаты проведенной апробации экспериментальной техники обезоруживания противника, вооруженного холодным оружием, во время учебно-тренировочных занятий по специальной физической подготовке. Изложены результаты экспериментальных исследований, направленных на повышение надежности зашиты от холодного оружия. Во время исследований использовалась видеокомпьютерная система экспресс-анализа техники единоборств (ВКС “Katsumoto”). Согласно полученным результатам разработаны экспериментальные модели техники обезоруживания, которые во время апробации значительно повысили технический арсенал курсантов - будущих правоохранителей МВД Украины.

Ключевые слова: специальная физическая подготовка, военнослужашие, полицейские, специально-подготовительные упражнения, техническая подготовка, современные технические средства обучения, защчита от угрозы холодным оружием, обезоруживание, правонарушитель, противник.

\section{УДК 796.22;796.07}

\author{
O. A. Morgunov, O. A. Yareshenko, O. V. Khatsayuk, Yu. K. Beloshenko
}

\section{DEVELOPMENT OF THE HAND-TO-HAND FIGHTING OF LAW ENFORCEMENT OFFICERS OF THE MIA OF UKRAINE IN THE SYSTEM OF SPECIAL PHYSICAL TRAINING}

The article presents the results of experimental studies aimed at increasing the reliability of protection against cold weapons. The pedagogical experiment was attended by cadets of junior high (military and police) school in the number of 40 people. The experiment lasted three months, during which 36 practical classes were held for 90 minutes each. On the eve of the pedagogical experiment, an analysis of scientific and methodological literature and Internet sources on service and applied martial arts was conducted. 
In accordance with the obtained theoretical components, a step-by-step plan for the development and improvement of experimental methods of hand-to-hand combat was developed. The evaluation of the technique of performing experimental techniques was carried out by expert estimation. In the course of researches, the video-computer system of express-analysis of technique of martial arts (VKS "Katsumoto") was used, which greatly increased the technical readiness of the studied cadets of the experimental group. At all stages of the pedagogical experiment, video shooting was widely used, which allowed a qualitative correction of hand-to-hand fighting techniques. In accordance with the obtained results, experimental models of disarmament technology have been developed, which during the testing significantly improved the technical arsenal of cadets-law enforcement officers.

Keywords: special training, military personnel, police officers, special training exercises, technical training, modern technical means of training, protection against the threat of cold weapons, disarmament, offender, and opponent.

Моргунов Олександр Анатолійович - заслужений тренер України, кандидат юридичних наук, доцент, завідувач кафедри спеціальної фізичної підготовки Харківського національного університету внутрішніх справ

https://orcid.org/0000-0003-2259-3620

Ярещенко Олег Артурович - кандидат наук з фізичного виховання та спорту, доцент, доцент кафедри спеціальної фізичної підготовки Харківського національного університету внутрішніх справ https://orcid.org/0000-0002-2475-7572

Хацаюк Олександр Володимирович - заслужений тренер України, заступник начальника кафедри фізичної підготовки та спорту Національної академії Національної гвардії України https://orcid.org/0000-0002-4166-9099

Белошенко Юрій Костянтинович - старший викладач кафедри фізичної підготовки та спорту Національної академії Національної гвардії України https://orcid.org/0000-0003-0521-676X 